\title{
RIVER DEVELOPMENT AND INCISION ON DOMINICA, WEST INDIES
}

COLE JIMERSON, The College of Wooster

Research Advisor: Amanda Schmidt

\section{INTRODUCTION}

Understanding the tectonic and climatic forces influencing the shape and history of Earth's surface has become a key undertaking in geomorphology (Gonzalez et al., 2016). Throughout the world, controls on river development include tectonics, bedrock lithology, storm pulses, landslides, and glaciers (Pike, 2010). Climatic and topographic variables such as mean basin slope, basin relief, seismicity, and precipitation have previously shown strong influence on erosion and incision rates (Portenga and Bierman, 2011; Covault et al., 2013; Willenbring et al., 2013; Harel et al., 2016). Although controls on erosion rates have been determined in many diverse landscapes, there has been little work on understanding river development and controls in the Lesser Antilles (Allen, 2017).

The tropical volcanic rivers on Dominica make up one of the largest river densities in the world and are accompanied by steep slopes, high mean annual rainfall, many landslides, and tropical storms creating a highly erosive landscape (Table 1; Neumann et al., 1978; Reading, 1991; Goldsmith et al., 2010; Ogden, 2016). Determining spatial patterns of geomorphic characteristics such as local relief, slope, rainfall, and channel steepness across Dominica brings insights of the effects of volcanic activity, tropical humid climate, great relief, and tropical storm pulses on geomorphic processes occurring on Caribbean islands. Minimum incision rates provide insights into the pace of river incision following pyroclastic flows filling the valleys. Long profiles show trends in channel gradients and are used to understand lithological influences on river down cutting (Duvall et al., 2004; Cyr et al., 2014).
Comparisons between incision rates to local climatic, lithological, topographic variables and long profiles allow for relative controls on geomorphic process to be established.

Table 1. Climatic and topographic geomorphic characteristics of the 20 largest rivers on Dominica.

\begin{tabular}{|c|c|c|c|c|c|c|}
\hline Name & $\begin{array}{l}\text { Local } \\
\text { Relief } \\
\text { (m) }\end{array}$ & $\begin{array}{c}\text { M.A.P } \\
\text { (mm/year) }\end{array}$ & $\begin{array}{c}\text { Mean } \\
\text { Basin } \\
\text { Slope } \\
(\%)\end{array}$ & $\begin{array}{l}\text { Area } \\
\left(\mathrm{km}^{2}\right)\end{array}$ & $\begin{array}{c}\% \text { Area } \\
\text { Landslide } \\
\text { Covered (landslides } \\
\text { mapped) }\end{array}$ & $\begin{array}{l}\text { Mean chi } \\
\text { coordinate }\end{array}$ \\
\hline Geneva River & 1471.9 & 4592.7 & 26.2 & 1723.8 & $24.69 \%(140)$ & 3.04 \\
\hline Lamothe River & 597.7 & 3312.2 & 23.2 & 306.9 & $0.00 \%(0)$ & 2.73 \\
\hline Blenheim River & 590.7 & 3684.6 & 18.8 & 1850.1 & $2.67 \%(23)$ & 3.25 \\
\hline Hampstead River & 1132.4 & 5156.2 & 18.9 & 1994.5 & $0.27 \%(7)$ & 4.81 \\
\hline Picard River & 781.9 & 3774.9 & 18.9 & 685.9 & $0.00 \%(0)$ & 3.56 \\
\hline Espagnole River & 1132.2 & 3577.5 & 16.8 & 1371.8 & $3.33 \%(5)$ & 4.71 \\
\hline Batali River & 1099.3 & 4653.6 & 20.8 & 1245.5 & $5.40 \%(18)$ & 3.71 \\
\hline $\begin{array}{l}\text { Macoucherie } \\
\text { River }\end{array}$ & 786.3 & 5235.8 & 19.7 & 1787.0 & $40.51 \%(103)$ & 4.41 \\
\hline Layou River & 1429.4 & 5555.2 & 16.6 & 6389.7 & $17.23 \%(139)$ & 5.89 \\
\hline Belfast River & 1485.6 & 4197.3 & 19.0 & 1832.1 & $5.48 \%(41)$ & 3.35 \\
\hline $\begin{array}{l}\text { Mamelabou } \\
\text { River }\end{array}$ & 568.1 & 4435 & 15.1 & 1254.5 & $11.93 \%(12)$ & 4.66 \\
\hline Toulaman River & 1057.4 & 5062.3 & 16.6 & 1543.3 & $1.92 \%(17)$ & 5.36 \\
\hline $\begin{array}{l}\text { Melville Hall } \\
\text { River }\end{array}$ & 949.1 & 5512.8 & 16.0 & 3086.6 & $5.09 \%(7)$ & 4.66 \\
\hline $\begin{array}{l}\text { Pagua River } \\
\text { (North) }\end{array}$ & 621.3 & 4866.6 & 19.0 & 694.9 & $2.89 \%(4)$ & 3.21 \\
\hline $\begin{array}{l}\text { Pagua River } \\
\text { (South) }\end{array}$ & 629.6 & 5069 & 17.2 & 1732.8 & $2.69 \%(16)$ & 4.25 \\
\hline $\begin{array}{l}\text { Castle Bruce } \\
\text { River }\end{array}$ & 1340.2 & 5624.9 & 17.2 & 2545.1 & $8.79 \%(84)$ & 3.12 \\
\hline White River & 1500.1 & 5157.2 & 27.1 & 1588.4 & $20.14 \%(82)$ & 2.92 \\
\hline Rosalie River & 1452.1 & 5922 & 23.7 & 3113.6 & $19.74 \%(75)$ & 3.68 \\
\hline Boeri River & 1474.4 & 4694.9 & 20.3 & 1407.9 & $11.74 \%(35)$ & 4.05 \\
\hline Roseau River & 1461.1 & 5091.5 & 21.0 & 2815.8 & $31.59 \%(126)$ & 4.29 \\
\hline
\end{tabular}

\section{METHODS}

A variety of topographic, climatic, and geologic variables (elevation, slope, rainfall, lithology) are compared to minimum rates of incision. To analyze spatial patterns of steepness, local relief and basinaverage slope were calculated using the Advanced 
Spaceborne Thermal Emission and Reflections Radiometer (ASTER) Global Digital Elevation Model (GDEM) Version 2 (NASA et al., 2009). Basinaveraged mean annual rainfall was calculated using precipitation data from Lang (1967). Landslide data was collected by Marcus Hall (Oberlin College) and Haley Talbot-Wendlandt (Ohio Wesleyan University), determining the total amount of landslides in each watershed and the area covered by landslides using Google Earth (Tomenchok et al., 2017). Channel profile analysis was completed using LSDTopoTools (Mudd et al., 2014). LSDTopoTools extracts the (chi) $\chi$ coordinate value, which represent the steepness of the river normalized for the upstream area and show the channel gradient throughout the entire river (Mudd et al., 2014). Long profiles of the rivers were created using LSDTopoTools then resampled using the geologic map of Dominica to determine the type of rock that is underlying the channel (Roobol and Smith, 2004). The steepness of the channel typically increases as the streams experience transitions in rock strengths, while consistently weak rock strengths yield lower channel slopes (Duvall et al., 2004).

Incision rates were determined for nine of the rivers on Dominica using ArcGIS (Fig. 1). Ignimbrite age dates for the sampled rivers were previously established from zircon dating (Howe et al., 2014; Frey et al., 2015). Transects across the channels were created within the extent of the dated ignimbrites. Once transects were created, the changes in elevation from the top to the bottom of the channels were recorded and divided by the age of the ignimbrites to determine minimum incision rate.

\section{RESULTS}

\section{Geomorphic Characteristics}

To quantify the characteristics of the rivers of Dominica, basin average statistics were determined for topographic and climatic variables that influence erosional processes. Digitalizing and extracting mean annual rainfall data from Lang (1967), average annual rainfall of the 20 watersheds on Dominica is 4759 $\mathrm{mm} / \mathrm{yr}$. Watersheds on the eastern side of the island have mean annual precipitation rates approximately $600 \mathrm{~mm} / \mathrm{yr}$ greater than the watersheds on the western side. The local relief, difference of the minimum

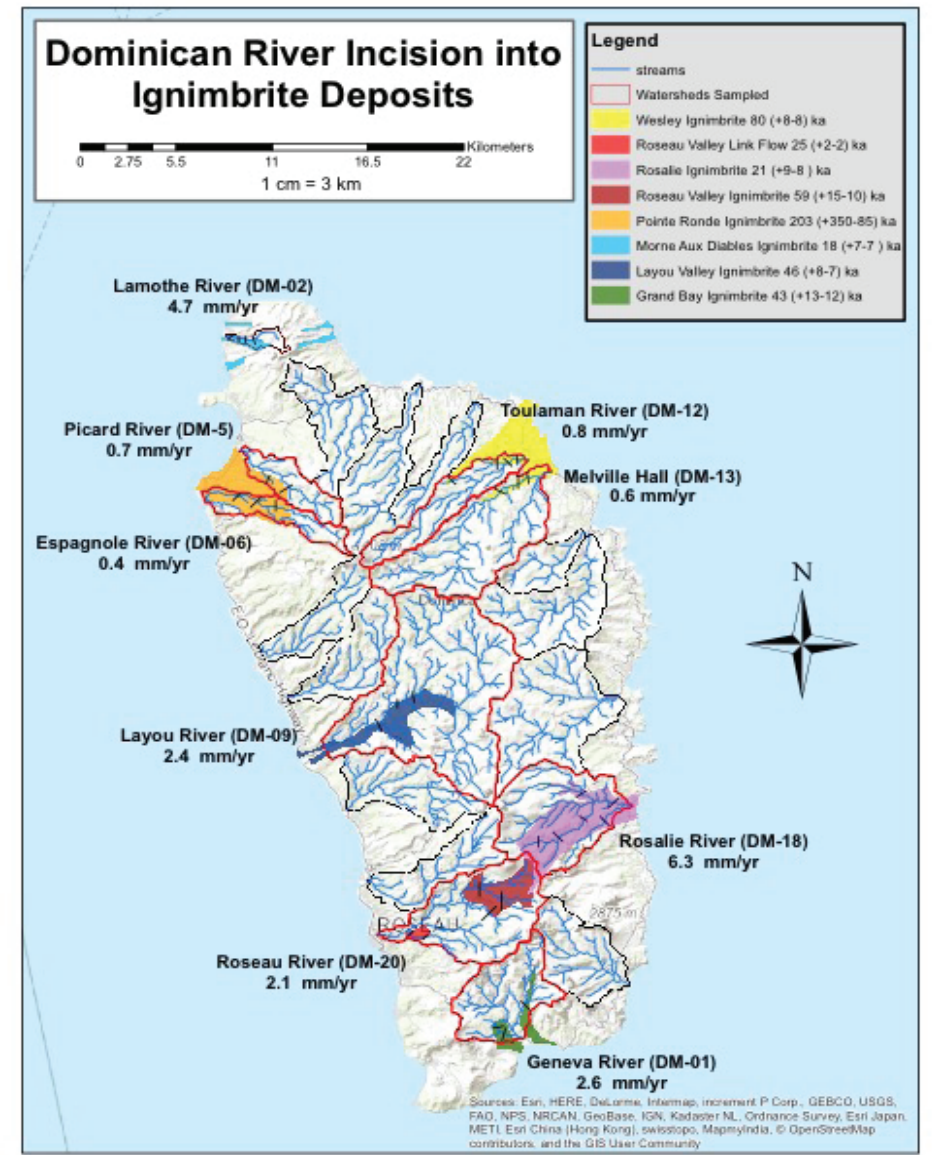

Figure 1. Average rates of minimum incision into the underlying ignimbrite deposits are the greatest in the southern rivers. Lowest rates of incision are in the northern rivers, with the exception of the northern-most Lamothe river.

and maximum elevations, and mean basin slope are the highest in the southern watersheds while local relief and slope are much lower in northern watersheds (Table 1). Linear regressions comparing the geomorphic characteristics of Dominica show that mean annual rainfall correlates strongly with mean normalized channel steepness (chi). Of the 934 landslides mapped, the southern watersheds tended to have the greatest number of landslides and percentage of area covered in landslides.

\section{Incision Rates}

Minimum incision rates were established for nine rivers on Dominica (Fig. 1) using transects across the river channels that flow through dated ignimbrite deposits (Howe et al., 2014; Frey et al., 2015). Incision rates of the rivers are relatively higher in the south of the island, except for the northernmost Lamothe River, which had the second highest average 


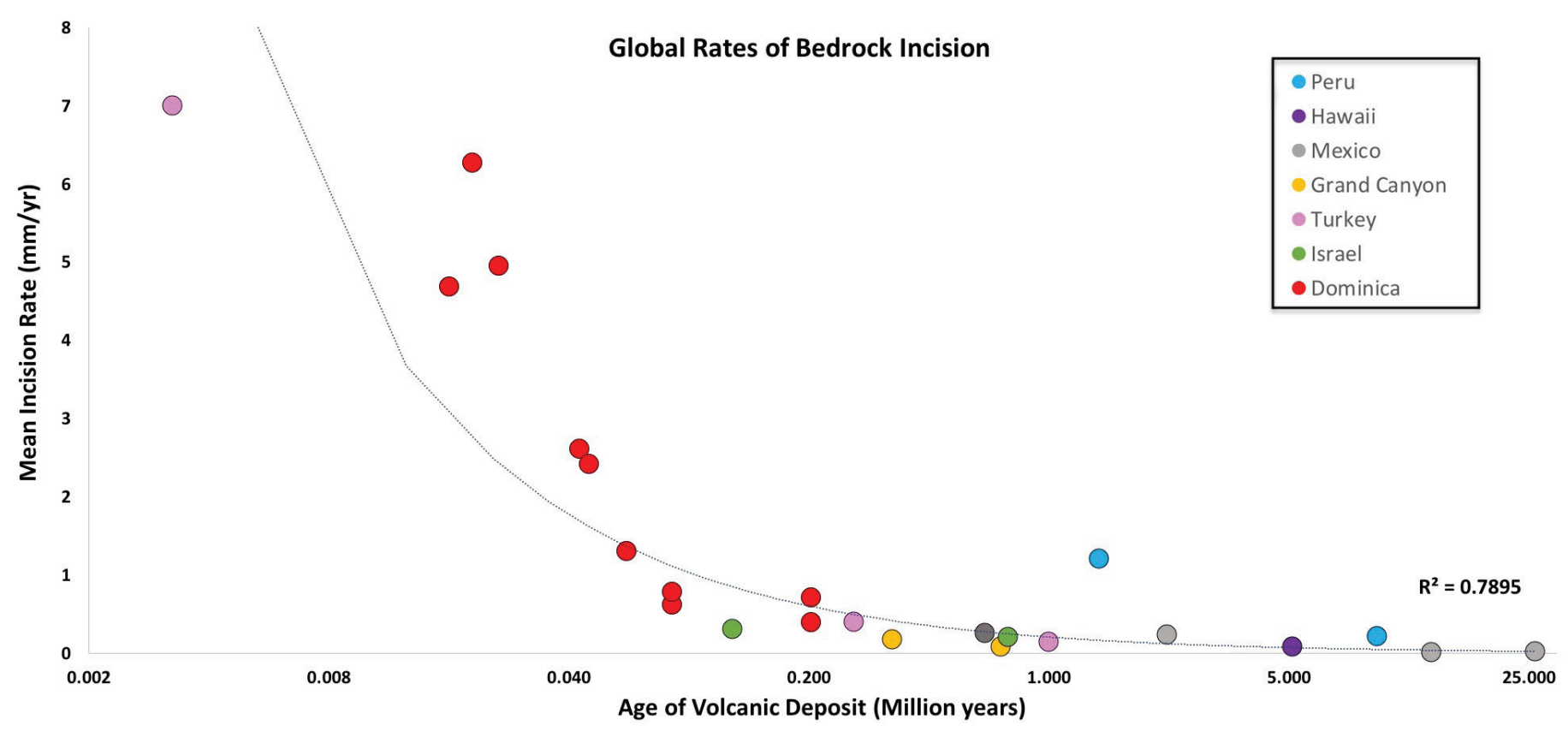

Figure 2. Incision rates show an exponential decrease with increasing ignimbrite age until $\sim 80$ ka where incision rates decrease much slower (Howe et al., 2014; Frey et al., 2015). The rivers that are incising into younger ignimbrite deposits that are less than $\sim 50 \mathrm{ka}$, showed higher incision rates and had a broader range in rates. Rivers incising older ignimbrites ( 80 - 200ka) have more consistent lower incision rates. Previous studies show that this trend continues as bedrock ages increase, showing minor decreases in incision after $\sim 200 \mathrm{ka}$.

incision rate $(4.7 \mathrm{~mm} / \mathrm{yr})$ (Fig. 1). The Rosalie River in the southeast had the highest minimum incision rate $(6.3 \mathrm{~mm} / \mathrm{yr})$ into the Rosalie ignimbrite (Fig. 1). The Rosalie, Roseau, Geneva, and Layou Rivers in the south, with the higher incision rates, tended to have the greatest local relief and mean basin slope (Table 1). Linear regressions show incision rates of the nine rivers are significantly correlated with mean normalized channel steepness $(\mathrm{chi})(\mathrm{p}<0.05)$ and the percent of the basin area covered in mapped landslides $(\mathrm{p}<0.05)$.

Incision rates tended to also be higher in younger ignimbrite deposits (Fig. 1, 2). Rivers with ignimbrite deposits less than $\sim 50 \mathrm{ka}$ have the highest rates of incision ranging from $2.1-6.3 \mathrm{~mm} / \mathrm{yr}$ (Fig. 2). Although the Wesley Ignimbrite is slightly younger than the Pointe Ronde Ignimbrite, the rivers flowing through both are experiencing similarly low rates of incision $(0.4-0.7 \mathrm{~mm} / \mathrm{yr})$ (Fig. 2).

\section{Channel Analysis}

Long profiles show that rivers with high incision rates into ignimbrite deposits have steeper slopes in the ignimbrite sections of the main channel, while rivers with low incision rates show lower slopes in ignimbrite sections (Fig. 3). The Roseau, Layou, and Rosalie Rivers, with high incision rates display the greatest slope in the channel segments of ignimbrite which occur frequently throughout the profiles (Fig. 1,3). In the Toulaman, Melville Hall, and Espagnole Rivers, with low incision rates, long profiles show decreased slopes in ignimbrite sections and primarily consist of block and ash flow deposits rather than ignimbrite deposits (Fig. 3). The slope gradient in these channel profiles is greater in the block and ash flow deposits and display a much more linear shape, lacking any distinct knickpoints.

\section{DISCUSSION}

The rivers on Dominica, like many volcanic landscapes that are responding to eruptions, show increased initial incision followed by exponential 


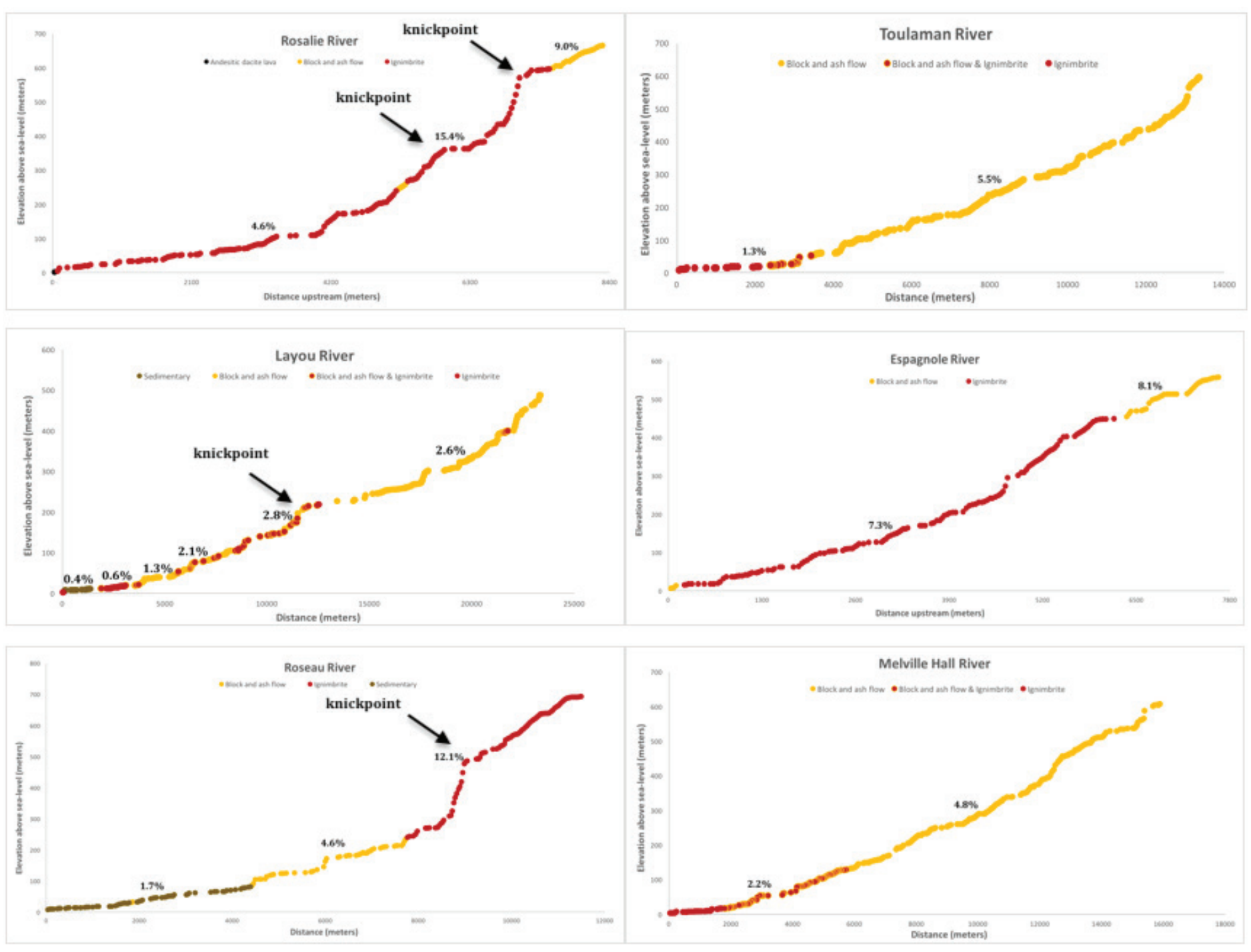

Figure 3. (Right) The Espagnole, Melville Hall, and Toulaman Rivers show steeper slopes in channel segments of block and ash flow deposits than segments of ignimbrite. These northern rivers also had the lowest minimum incision rates (0.4 -0.8 mm/yr), than the southern rivers with higher incision and steeper channels in ignimbrite segments. (Left) Ignimbrite deposit segments are the steepest in The Roseau, Layou, and Rosalie Rivers showing distinct knickpoints in these areas. The increasing steepness in ignimbrite sections in these channels align well with the higher rates of minimum incision $(6.3-2.4 \mathrm{~mm} / \mathrm{yr})$ that the rivers are experiencing.

decrease over time (Thouret, 1999). Incision rates into young ignimbrite deposits less than $\sim 25 \mathrm{ka}$ are very high and are reduced to approximately half in ignimbrite deposits that are between $\sim 43-46$ ka (Fig. 2). This pattern continues with increasing ignimbrite age as deposits $\sim 59$ ka drop approximately $50 \%$ again. (Howe et al., 2014; Frey et al., 2015). Incision rates into ignimbrite deposits show a distinct tendency of decreasing around $50 \%$ every $\sim 20 \mathrm{ka}$ (Fig. 2). After $\sim 80 \mathrm{ka}$, incision rates begin to decrease at a progressively slower pace. Incision rates into much older ignimbrite deposits in Peru (Thouret et al., 2007) and Mexico (Montgomery et al., 2003) demonstrate a similar result with incision in deposits $<1.4$ Ma being five times greater than incision into deposits $9-13 \mathrm{Ma}$ and continuing to decrease as ages increase (Fig. 2). Studies on river incision into basalt lava flows followed a similar trend, where local incision rates were lower in the oldest deposits, with all deposits $>100 \mathrm{ka}$ having incision rates below $0.4 \mathrm{~mm} / \mathrm{yr}$ (Fig. 2; Seidl et al., 1994; Righter et al., 1997; Karlstrom et al., 2007; Seyrek et al., 2008; Maddy et al., 2012; van Gorp et al., 2013; Shtober-Zisu et al., 2017). Long profiles further express this pace of incision as rivers with higher incision rates and younger ignimbrite deposits show multiple knickpoints that represent changes in lithology and erodibility (Cyr et al., 2014) and steeper channel slopes throughout ignimbrite segments (Fig. 3). 
On the other hand, rivers with lower incision rates lacked knickpoints and had less lithological changes throughout the channels, suggesting that the rivers have fully incised through these ignimbrite deposits reaching the less erodible underlying bedrock.

The incision rates of Dominica's rivers into the ignimbrite deposits are greater in southern watersheds that tended to have both higher mean basin slopes, local relief, and more area covered by landslides (Fig. 4). Although relief and slope have been shown to correlate with erosion, the percent of watershed area covered in landslides and mean (chi) normalized channel gradient show the strongest influence on incision rates $(p<0.05)$. Increased landsliding is how hillslopes adjust in response to rapid fluvial incision (Burbank et al., 1996) and is a primary mechanism in which landscapes respond to high rates of tectonic uplift (Montgomery and Brandon, 2002; Larson and
Montgomery, 2012). Mean incision rates significantly influence mean channel steepness as increased downcutting leads to channels becoming steeper and have been directly linked to increased erosion especially after hillslopes reach their slope threshold (Kirby and Whipple, 2001; Lague and Davy, 2003; Safran et al., 2005; Wobus et al., 2006). Ultimately, the high annual rainfall, basin slope, and local relief, causes increased landslides and channel steepness, allowing incision to be higher in the southern watersheds.

\section{CONCLUSION}

Dominica gives us insights into younger Pleistocene ignimbrite incision rates over the past $\sim 200 \mathrm{ka}$. Our data suggest that mean incision rates of $4.67-6.26$ $\mathrm{mm} / \mathrm{yr}$ since $\sim 18-25 \mathrm{ka}$, decrease approximately $50 \%$ every $\sim 20 \mathrm{ka}$ until $\sim 80 \mathrm{ka}$, when incision rates reach $0.61-0.78 \mathrm{~mm} / \mathrm{yr}$ and remain similar in
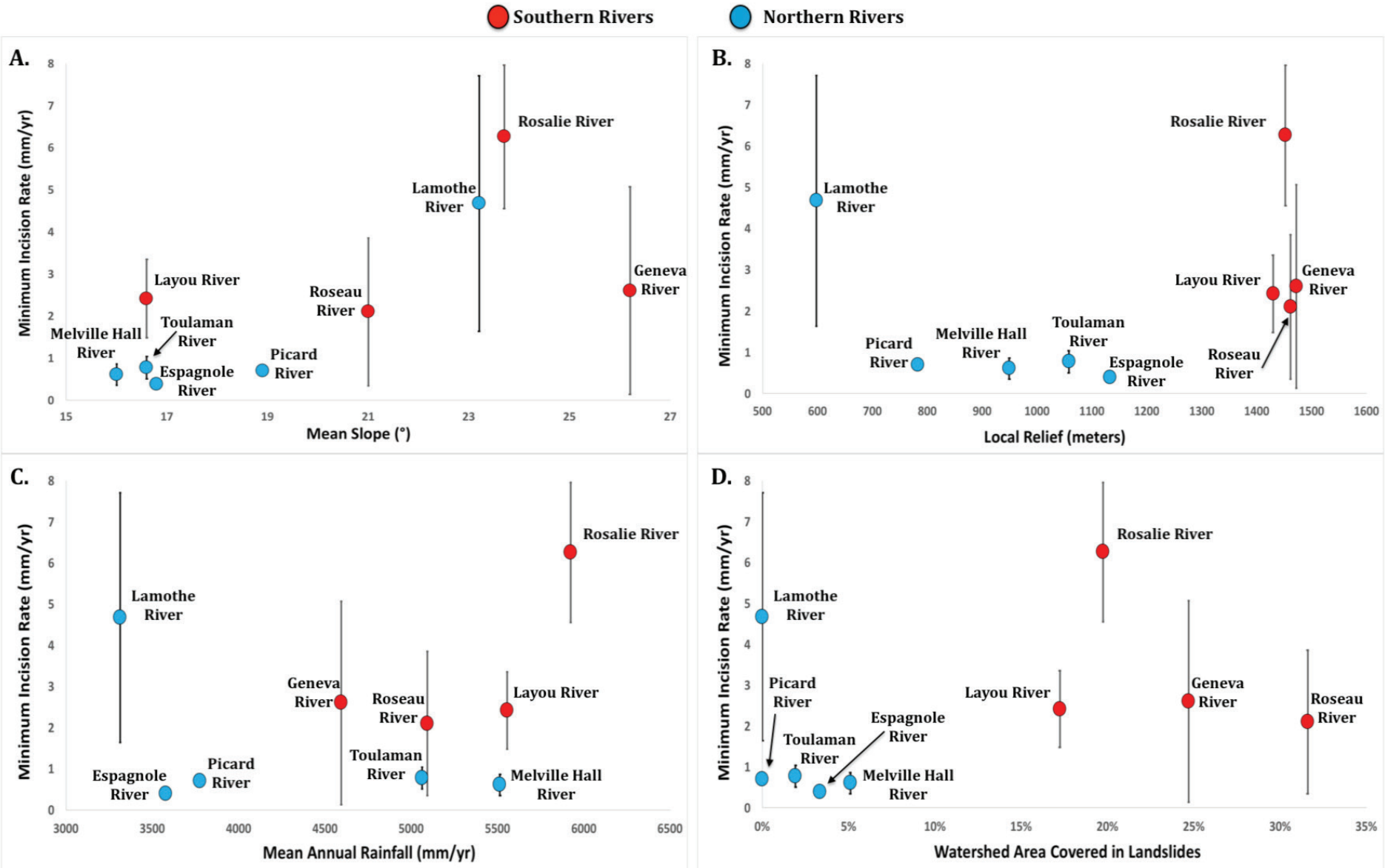

Figure 4. Incision rates across Dominica compared to influential geomorphic characteristics exhibiting both higher rates of incision and topographic/climatic variables in the southern watersheds (red). Northern watersheds (blue) with lower incision rates typically had lower (A.) mean basin slopes, (B.) local relief, (C.) mean annual rainfall, and (D.) area covered in landslides. 
$\sim 203 \mathrm{ka}$ ignimbrite deposits at $0.39-0.7 \mathrm{~mm} / \mathrm{yr}$ (Fig. $2)$. Incision rates were most significantly correlated with the percent of watershed area landslide covered, identifying that hillslopes respond to fast fluvial incision through increased frequency of landsliding (Burbank et al., 1996, Montgomery and Brandon, 2002). Normalized chi coordinate values correlated significantly with mean incision rates, strengthening the relationship between river incision and channel steepness that lead to increased erosion (Safran et al., 2005). Long profiles of the rivers on Dominica present lithologic controls on incision, where steep slopes and knickpoints are prominent in segments of the channel consisting of ignimbrite (Fig. 3). Correlations between mean (chi) normalized channel steepness and landslide coverage with incision rates, show that increased climatic and topographic variables drive incision process through landsliding and channel steepening.

\section{ACKNOWLEDGEMENTS}

This material is based upon work supported by the Keck Geology Consortium and the National Science Foundation under Grant No. 1659322. I would like to thank the Keck Geology Consortium for the research opportunity and experience to conduct research on Dominica, West Indies and the Dominica Ministry of Forestry for providing permits for this research. Thanks to Holi Frey at Union College for coordinating the Keck project and my Keck Advisor Amanda Schmidt at Oberlin College for the information and data required to carry out this study. Special thanks go to the Geomorph research team: Marcus Hall, Kira Tomenchok, and Haley Talbot-Wendlandt for assistance in the field, lab and supplying data for this study.

\section{REFERENCES}

Allen, C.D., 2017, Landscapes and Landforms of the Lesser Antilles: Springer, p. 326.

Burbank, D.W., Leland, J., Fielding, E., and Anderson, R.S., 1996, Bedrock incision, rock uplift and threshold hillslopes in the northwestern Himalayas: Nature, v. 379, p. 505.

Covault, J.A., Craddock, W.H., Romans, B.W., Fildani, A., and Gosai, M., 2013, Spatial and Temporal Variations in Landscape Evolution: Historic and Longer-Term Sediment Flux through Global Catchments: The Journal of Geology, v. 121, p. 35-56.

Cyr, A.J., Granger, D.E., Olivetti, V., and Molin, P., 2014, Distinguishing between tectonic and lithologic controls on bedrock channel longitudinal profiles using cosmogenic ${ }^{10} \mathrm{Be}$ erosion rates and channel steepness index: Geomorphology, v. 209, p. 27-38.

Duvall, A., Kirby, E., and Burbank, D., 2004, Tectonic and lithologic controls on bedrock channel profiles and processes in coastal California: Journal of Geophysical Research: Earth Surface, v. 109, p. F03002.

Frey, H.M., Manon, M.R., and Brehm, S., 2015, Fingerprinting young ignimbrites in Dominica (Lesser Antilles): Constraints from bulk REEs, apatite chemistry, and U-Th zircon chronology: AGU Fall Meeting Abstracts, http://adsabs. harvard.edu/abs/2015AGUFM.V51F3104F (accessed October 2017).

Goldsmith, S.T., Carey, A.E., Johnson, B.M., Welch, S.A., Lyons, W.B., McDowell, W.H., and Pigott, J.S., 2010, Stream geochemistry, chemical weathering and $\mathrm{CO}_{2}$ consumption potential of andesitic terrains, Dominica, Lesser Antilles: Geochimica et Cosmochimica Acta, v. 74, p. 85-103.

Harel, M.-A., Mudd, S.M., and Attal, M., 2016, Global analysis of the stream power law parameters based on worldwide ${ }^{10} \mathrm{Be}$ denudation rates: Geomorphology, v. 268, p. 184-196. 
Howe, T.M., Schmitt, A.K., Lindsay, J.M., Shane, P., and Stockli, D.F., 2015, Time scales of intraoceanic arc magmatism from combined U-Th and (U-Th)/He zircon geochronology of Dominica, Lesser Antilles: Geochemistry, Geophysics, Geosystems, v. 16, p. 347-365.

Karlstrom, K.E., Crow, R.S., Peters, L., McIntosh, W., Raucci, J., Crossey, L.J., Umhoefer, P., and Dunbar, N., 2007, ${ }^{40} \mathrm{Ar} /{ }^{39} \mathrm{Ar}$ and field studies of Quaternary basalts in Grand Canyon and model for carving Grand Canyon: Quantifying the interaction of river incision and normal faulting across the western edge of the Colorado Plateau: GSA Bulletin, v. 119, p. 1283-1312.

Kirby, E., and Whipple, K., 2001, Quantifying differential rock-uplift rates via stream profile analysis: Geology, v. 29, p. 415.

Lague, D., Crave, A., and Davy, P., 2003, Laboratory experiments simulating the geomorphic response to tectonic uplift: GEOMORPHIC RESPONSE TO TECTONIC UPLIFT: Journal of Geophysical Research: Solid Earth, v. 108, p. ETG 3-1-ETG 3-20.

Lang, D.M., 1967, Soil and land-use surveys No. 21. Dominica.: Soil and land-use surveys No. 21. Dominica., https://www.cabdirect.org/cabdirect/ abstract/19721905097 (accessed January 2018).

Larsen, I.J., and Montgomery, D.R., 2012, Landslide erosion coupled to tectonics and river incision: Nature Geoscience, v. 5, p. 468-473.

Maddy, D., Demir, T., Veldkamp, A., Bridgland, D.R., Stemerdink, C., Schriek, T.V.D., and Schreve, D., 2012, The obliquity-controlled early Pleistocene terrace sequence of the Gediz River, western Turkey: a revised correlation and chronology: Journal of the Geological Society, v. 169, p. 67-82.

Montgomery, D.R., and Brandon, M.T., 2002, Topographic controls on erosion rates in tectonically active mountain ranges: Earth and Planetary Science Letters, v. 201, p. 481-489.

Montgomery, D.R., and López-Blanco, J., 2003, PostOligocene river incision, southern Sierra Madre Occidental, Mexico: Geomorphology, v. 55, p. 235-247.
Mudd, S.M., Attal, M., Milodowski, D.T., Grieve, S.W.D., and Valters, D.A., 2014, A statistical framework to quantify spatial variation in channel gradients using the integral method of channel profile analysis: CHANNEL SEGMENT FITTING: Journal of Geophysical Research: Earth Surface, v. 119, p. 138-152.

NASA/METI/AIST/Japan Spacesystems, and U.S./ Japan ASTER Science Team, 2009, ASTER Global Digital Elevation Model: Terra ASTER v. 2. NASA EOSDIS Land Processes DAAC, "ASTER GDEM is a product of METI and NASA." doi: 10.5067/ASTER/ASTGTM.002. Neuman, C.J., Cry, G.W., Caso, E.L., and Jarvinen, B.R., 1978, Tropical cyclones of the north Atlantic Ocean, 1871-1977: National Climatic Center. US Department of Commerce. National Oceanic and Atmospheric Administration.

Asheville, NC.

Ogden, F.L., 2016, Evidence of equilibrium peak runoff rates in steep tropical terrain on the island of Dominica during Tropical Storm Erika, August 27, 201: Journal of Hydrology, v. 542, p. 35-46.

Pike, A.S., Scatena, F.N., and Wohl, E.E., 2010, Lithological and fluvial controls on the geomorphology of tropical montane stream channels in Puerto Rico: Earth Surface Processes and Landforms, v. 35, p. 1402-1417.

Portenga, E.W., and Bierman, P.R., 2011, Understanding Earth's eroding surface with 10Be: GSA Today, v. 21, p. 4-10.

Reading, A.J., 1991, Stability of tropical residual soils from Dominica, West Indies: Engineering Geology, v. 31, p. 27-44.

Righter, K., 1997, High bedrock incision rates in the Atenguillo River valley, Jalisco, Western Mexico: Earth Surface Processes and Landforms, v. 22, p. 337-343.

Roobol, M.J. and Smith, A.L., 2004, Geologic Map of Dominica, West Indies: CHARIM (Caribbean Handbook on Risk Information Management), 2016, http://charim-geonode.net/layers/ geonode:geology_dominica\#more.

Safran, E.B., Bierman, P.R., Aalto, R., Dunne, T., Whipple, K.X., and Caffee, M., 2005, Erosion rates driven by channel network incision in the Bolivian Andes: Earth Surface Processes and Landforms, v. 30, p. 1007-1024. 
Seidl, M.A., Dietrich, W.E., and Kirchner, J.W., 1994, Longitudinal Profile Development into Bedrock: An Analysis of Hawaiian Channels: The Journal of Geology, v. 102, p. 457-474.

Seyrek, A., Demir, T., Pringle, M., Yurtmen, S., Westaway, R., Bridgland, D., Beck, A., and Rowbotham, G., 2008, Late Cenozoic uplift of the Amanos Mountains and incision of the Middle Ceyhan river gorge, southern Turkey; ArAr dating of the Düziçi basalt: Geomorphology, v. 97, p. 321-355.

Shtober-Zisu, N., Inbar, M., Mor, D., Jicha, B.R., and Singer, B.S., 2018, Drainage development and incision rates in an Upper Pleistocene BasaltLimestone Boundary Channel: The Sa'ar Stream, Golan Heights, Israel: Geomorphology, v. 303, p. 417-433.

Sosa Gonzalez, V., Bierman, P.R., Fernandes, N.F., and Rood, D.H., 2016, Long-term background denudation rates of southern and southeastern Brazilian watersheds estimated with cosmogenic ${ }^{10}$ Be: Geomorphology, v. 268, p. 54-63.

Thouret, J. C., 1999, Volcanic geomorphology - an overview: Earth-Science Reviews, v. 47, p. 95-131.

Thouret, J.-C., Wörner, G., Gunnell, Y., Singer, B., Zhang, X., and Souriot, T., 2007, Geochronologic and stratigraphic constraints on canyon incision and Miocene uplift of the Central Andes in Peru: Earth and Planetary Science Letters, v. 263, p. 151-166.

Tomenchok, K., Jimerson, C., Talbot-Wendlandt, H., and Hill, M., 2017, Landslides and Volcanoes: Fingerprinting Erosional Processes on a tropical island, Lesser Antilles: AGU Fall Meeting Abstracts.

Van Gorp, W., Veldkamp, A., Temme, A.J.A.M., Maddy, D., Demir, T., van der Schriek, T., Reimann, T., Wallinga, J., Wijbrans, J., and Schoorl, J.M., 2013, Fluvial response to Holocene volcanic damming and breaching in the Gediz and Geren rivers, western Turkey: Geomorphology, v. 201, p. 430-448.

Willenbring, J.K., Codilean, A.T., and McElroy, B., 2013, Earth is (mostly) flat: Apportionment of the flux of continental sediment over millennial time scales: Geology, v. 41, p. 343-346.
Wobus, C., Whipple, K.X., Kirby, E., Snyder, N., Johnson, J., Spyropolou, K., Crosby, B., and Sheehan, D., 2006, Tectonics from topography: Procedures, promise, and pitfalls, in Special Paper 398: Tectonics, Climate, and Landscape Evolution, Geological Society of America, v. 398, p. 55-74. 